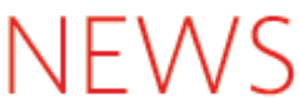

\title{
Advice on nuclear safety set for update in wake of floods
}

When Hurricane Katrina threatened the US coast, a nuclear power plant in the storm's path was shut down as a safety precaution. But, as last December's tsunami showed, there isn't always advance warning of floods.

Experts from 16 countries gathered in Kalpakkam, India, this week to discuss whether international safety standards for nuclear plants in flood-risk areas need to be modified. Kalpakkam is the site of India's prototype fastbreeder reactor, still under construction, which was partly flooded by 2004's Indian Ocean tsunami (see Nature 433, 675; 2005).

After that disaster, India's nuclear authorities hastily organized about a dozen national meetings to discuss lessons learned. This week's workshop, organized by the International Atomic Energy Agency (IAEA), was the first time Indian scientists and officials shared their experiences with the international community.

India operates six nuclear plants, and another site is scheduled to start operating by 2008. "Practically all sites are at risk of being flooded," says Saurabh Verma, a researcher at the National Geophysical Research Institute in Hyderabad.

Outside India, nuclear facilities at risk include plants in Japan and the United States that sit along the tsunami-prone Pacific rim. But most of the world's more than 430 nuclear power plants need stronger protection against flooding, meeting organizers say. Plants are often located near coasts, where they use sea water to help cool the reactor.

Fewer than half of the countries that operate
IMAGE

UNAVAILABLE FOR COPYRIGHT REASONS nudear power plants sent representatives to the meeting. Britain, Canada and Russia, for example, said they were unable to attend. But, based on the meeting's outcome, the IAEA will probably update its safety recommendations, which it last modified in 2003. National governments will then decide whether to adopt the voluntary standards.

The requirements include guidelines for the minimum distance of plants from the shore and the height and strength of protective walls. Post-tsunami surveys carried out in affected countries have yielded a wealth of information - about propagation of waves, run-up heights of water along different coasts, and the efficiency of flood warning systems - which safety experts can use to model the protection needed at given sites.

"From an engineering point of view, flood protection is easy," says Antonio Godoy, a senior safety officer with the IAEA. "The point is to come up with correct safety margins for specific sites, taking into account the local topography, flooding probability and inundation patterns. We need to ask ourselves, have we done enough or must we improve?"

In nuclear plants, flooding primarily affects the water intake and cooling systems. The greatest danger is that water could breach buildings that deal with plant safety, causing electrical short circuits or outright failures.

The worst flooding of a nuclear power plant in recent years occurred in December 1999 at the Blayaissite in France. The flood, which was triggered by a combination of a storm surge, high waves and an 'ordinary' river flood, rated two out of seven on the International Nuclear Event Scale, but experts admit it came dangerously close to a genuine nudear accident.

Power plants were also at risk during floods in Germany in 1997 and 2002. In the United States on 29 August, operators shut down the Waterford nuclear power plant near New Orleans as Hurricane Katrina approached. The US Nuclear Regulatory Commission sent additional staff to two other plants in the region.

"Tsunami risk is just one side of the problem," says Godoy. "A combination of events, such as extreme precipitation and abreach in a dyke, could be at least equally catastrophic." Quirin Schiermeier

Additional reporting by Valeska Stephan 